\title{
Analisis Pengaruh Penerapan Metode DRP Terhadap Bullwhip Effect Pada Rantai Suplai
}

\author{
Sri Rahayu, Departemen Teknik Industri, Institut Sains dan Teknologi Terpadu Surabaya dan \\ Pram Eliyah Yuliana, Departemen Teknik Industri, Institut Sains dan Teknologi Terpadu Surabaya
}

\begin{abstract}
Abstrak - Dalam sebuah rantai suplai, aliran informasi yang akurat dari setiap tahapan sangat penting untuk memenuhi kebutuhan konsumen. Distorsi informasi mengakibatkan pola permintaan yang semakin fluktuatif kearah hulu dalam rantai suplai. Meningkatnya fluktuasi atau variabilitas permintaan dari hilir ke hulu suatu rantai suplai dinamakan bullwhip effect (BE). Nilai BE didapat dari perbandingan antara kebutuhan dan pemesanan yang dilakukan untuk memenuhi permintaan. Nilai BE yang ideal adalah 1, yang berarti terdapat keseimbangan antara kebutuhan dan pemesanan yang dilakukan sehingga tidak menyebabkan penumpukan ataupun kekurangan persediaan. Ada beberapa hal yang bisa menyebabkan terjadinya bullwhip effect, diantaranya order batching, yaitu penentuan ukuran pemesanan pada setiap tahapan rantai suplai. Pada penelitian ini akan dilakukan analisis pengaruh penerapan metode Distribution Requirement Planning (DRP) terhadap Bullwhip Effect pada level sub distributor ke distributor utama. Distribution Requirement Planning adalah suatu metode untuk menangani pengadaan persediaan dalam suatu jaringan distribusi multi eselon Dengan membuat DPR maka pemesanan dapat direncanakan dengan baik sesuai dengan permintaan dari eselon dibawahnya dalam rantai suplai. Studi kasus dilakukan pada distributor minyak goreng UD Trimei yang melayani beberapa sub distributor di wilayah Jawa Timur dan diambil contoh dua jenis produk yaitu Hemart $500 \mathrm{ml}$ dan Hemart $1000 \mathrm{ml}$. Pada UD Trimei sering terjadi ketidaksesuaian stock karena tidak adanya perencanaan terhadap ketersediaan produk pada distributor ini. Masalah tersebut diselesaikan dengan metode distribution requirement planning untuk menentukan jumlah pemesanan pada perusahaan. Setelah metode ini diterapkan untuk merencanakan kebutuhan kedepan pada perusahaan ini, keadaan membaik yang ditandai dengan nilai bullwhip effect yang mendekati nilai 1. Nilai bullwhip effect sebelum penerapan metode distribution requirement planning pada produk Hemart $500 \mathrm{ml}$ adalah 3.18 sedang pada produk Hemart $1000 \mathrm{ml}$ adalah 2.89. Setelah penerapan metode distribution requirement planning nilai bullwhip effect Hemart $500 \mathrm{ml}$ menjadi 1.07 dan untuk produk Hemart $1000 \mathrm{ml}$ menjadi 0,99 .
\end{abstract}

Kata Kunci-Bullwhip Effect, Rantai Supplai, Order Batching, DRP.

\section{Pendahuluan}

$\mathrm{B}$ ullwhip merupakan suatu fenomena dimana pemesanan yang dilakukan kepada supplier mempunyai variasi yang besar dibandingkan dengan penjualan kepada konsumen.

Sri Rahayu, Departemen Teknik Industri, Institut Sains dan Teknologi Terpadu Surabaya, Surabaya, Jawa Timur, Indonesia

Pram Eliyah Yuliana, Departemen Teknik Industri, Institut Sains dan Teknologi Terpadu Surabaya, Surabaya, Jawa Timur, Indonesia
Peningkatan variabilitas ini bisa terjadi di setiap eselon pada rantai suplai akibat adanya distorsi informasi. Ada beberapa hal yang bisa menyebabkan terjadinya bullwhip effect, diantaranya order batching, yaitu penentuan ukuran pemesanan pada setiap tahapan rantai suplai.

UD. Trimei yang berada di kecamatan Talun, kabupaten Blitar, Jawa Timur merupakan salah satu distributor berbagai kebutuhan rumah tangga yang juga merupakan satu mata rantai pengadaan barang dari supplier kepada konsumen. UD. Trimei mendistribusikan beberapa jenis bahan pangan diantaranya minyak goreng, garam, wafer, kacang atom dan beberapa jenis pangan lainnya, dengan produk utamanya adalah minyak goreng. Produk minyak goreng yang didistribusikan berasal dari pabrik yang sama dengan minyak goreng Tropical. Namun minyak goreng yang didistribusikan oleh distributor ini adalah minyak goreng Hemart dan Fitri, yang bisa dibilang adalah minyak goreng dengan kualitas dibawah minyak Tropical namun masih satu perusahaan. Untuk jalur distribusinya sendiri mencakup wilayah daerah Blitar dan Tulungagung.

Didapati masalah yang terjadi pada perusahaan ini ada pada seringnya ketidaksesuaian persediaan produk. Hal ini dikarenakan perencanaan pemesanan produk pada distributor ini masih dilakukan secara manual dengan menggunakan perkiraan, intuisi atau kebiasaan, sehingga sering kali mengakibatkan terjadinya kekurangan atau kelebihan persediaan. Seperti contoh pernah terjadi out of stock yang dikarenakan permintaan yang tidak di perkirakan serta tidak adanya safety stock yang dimiliki. Tentunya hal ini juga akan berpengaruh terhadap efisiensi perusahaan ini.

\section{RUMUSAN MASAlaH DAN TUJUAN PENELITIAN}

Berdasarkan latar belakang yang telah diuraian diatas, maka dapat dirumuskan permasalahan dan tujuan sebagai berikut:

1) Bagaimana penjadwalan aktivitas distribusi minyak goreng yang optimal untuk sub distributor di wilayah Jawa Timur?

2) Bagaimana pengaruh penerapan DRP terhadap nilai BE di UD.Trimei?

\section{LANDASAN TEORI}

\section{A. Supply Chain Management}

Menurut Copra dan Meindl (2001) Supply Chain Management dapat didefinisikan sebagai aliran barang 
mulai dari pemasok melalui manufacture dan distribusinya ke end user atau sekumpulan set (alat), cara, atau pendekatan yang bertujuan untuk mengintegrasikan hubungan antara pemasok, manufacture, warehouse (depo), dan gudang agar berjalan secara efektif dan efisien, sehingga produk dapat diproduksi dan didistribusikan dalam jumlah dan lokasi yang benar dalam waktu yang tepat untuk mengurangi total biaya produksi,tetapi disisi lain permintaan tetap dapat dipenuhi dan keuntungan didapatkan [2]. Persoalan utama dalam mengatur supply chain adalah perkiraan permintaan/ kebutuhan (demand forecasting) dan waktu pengiriman karena hal ini bersifat tidak pasti (uncertainly).

\section{B. Bullwhip Effect}

Bullwhip effect mengakibatkan banyak inefisiensi pada supply chain [4]. Misalnya pabrik memproduksi dan mengirim lebih banyak dari yang sesungguhnya dibutuhkan akibat salah membaca signal permintaan dari pemain bagian hilir supply chain. Kegiatan dari pabrik dan pemasok lebih fluktuatif sehingga mereka sering lembur menghadapi pesanan yang berlebih atau menganggur karena distributor/ritel tidak memesan dalam waktu yang relatif panjang akibat mereka melakukan forward buying.

Bullwhip effect adalah suatu fenomena dimana satu lonjakan kecil di level konsumen akan mengakibatkan lonjakan yang sangat tajam di level yang jauh dari konsumen. Efek dari kondisi ini adalah semakin tidak akuratnya data permintaan. Berikut Ilustrasinya:

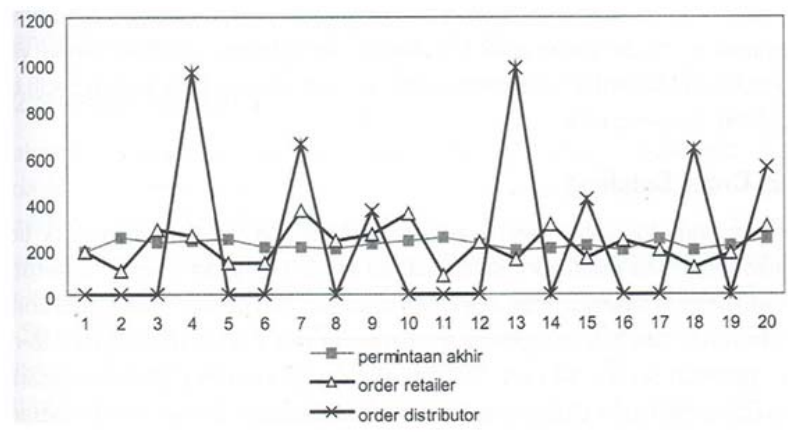

Gambar. 1. Grafik Ilustrasi BE

Ada 4 penyebab utama dari bullwhip effect [3] yaitu:

1) Demand

Yaitu permintaan yang jarang sekali stabil mengakibatkan peramalan permintaan yang kita buat juga jarang sekali akurat, sehingga terjadinya error pada forecast dimana perusahaan mengantisipasi dengan membuat safety stock.

2) Order Batching

Pada saat inventory pada perusahaan sudah menurun, maka perusahaan biasanya tidak langsung memesan barang, ini dikarenakan perusahaan memesan berdasar order batching atau akumulasi permintaan sebelum memesan pada supplier. Jadi yang dihadapi oleh supplier ketika perusahaan memesan secara periodik adalah terjadinya tingkat permintaan yang tinggi untuk bulan ini disusun dengan kekosongan di bulan berikutnya. Pemesanan secara periodik ini mengakibatkan bullwhip effect.

\section{3) Price Fluctuation}

Manufacture dan distributor biasanya membuat promosi secara periodikal, sehingga membuat pembeli melakukan permintaan menjadi lebih banyak dari yang sebenarnya dibutuhkan. Promosi semacam ini dapat membuat supply chain menjadi terancam, ini dikarenakan pembeli akan memesan lebih banyak dari yang dibutuhkan ketika sedang ada promosi dan ketika harga menjadi normal maka tidak ada pembelian karena customer masih memiliki stock barang. Dan variasi dari pembelian lebih besar dari variasi consumsion rate sehingga ini menimbulkan bullwhip effect.

4) Rationing and Shortage Gaming

Pada saat salah satu rantai dari supply chain management ada yang melakukan "permainan" yang mengakibatkan pabrik tidak mengetahui permintaan pasar yang sebenarnya sehingga terjadi kekurangan atau kelebihan stock di pasaran yang mengakibatkan kekacauan di downstream, atau ada salah satu mata rantai yang melakukan penimbunan barang agar terjadi scarcity dan menimbulkan kekacauan di mata rantai SCM, sehingga permintaan meningkat dari downstream. Ini juga mengakibatkan bullwhip effect.

Dan berikut adalah rumus dalam menghitung nilai BE:

$B E=C V o / C V d$

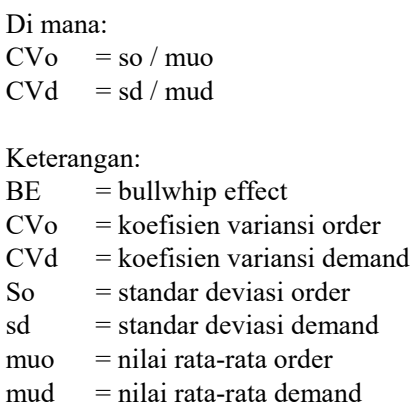

\section{Distribution Requirement Planning}

Menurut Bozarth dan Handfield (2008) Distribution Requirement planning merupakan aplikasi dari angka logika Material Requirement Planning (MRP) [1]. Persediaan Bill of Material (BOM) pada MRP diganti dengan Bill of Distribution (BOD) pada Distribution Requirement Planning (DRP) menggunakan logika Time Phased On Point (TPOP) untuk memerlukan pengadaan kebutuhan pada jaringan

Distribution Requirement Planning didasarkan pada peramalan kebutuhan pada level terendah dalam jaringan tersebut yang akan menentukan kebutuhan persediaan pada level yang lebih tinggi. Konsep umum DRP dapat dilihat pada gambar dibawah:

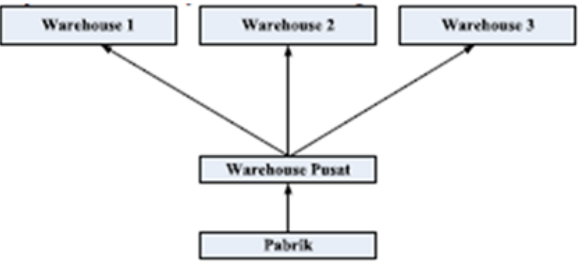

Gambar. 2. Struktur DRP 


\section{Metode Penelitian}

Tahapan penelitian yang dilakukan adalah sebagai berikut:

\section{A. Pengaturan Awal}

Sebagai langkah awal penelitian yang dilakukan adalah melakukan pengamatan terhadap kegiatan distribusi di perusahaan yang akan diteliti yaitu UD. TRIMEI. Pengamatan ini bertujuan untuk mengetahui masalah apa yang ada pada perusahaan ini.

\section{B. Perumusan Masalah}

Setelah melakukan pengamatan terhadap kegiatan distribusi di UD. TRIMEI maka akan ditemukan masalah masalah yang ada pada perusahaan ini. Maka dirumuskanlah masalah masalah apa saja yang terjadi dan akan dibahas dalam penelitian ini dan juga dilakukan penentuan tujuan daripada penelitian ini.

\section{Studi Pustaka}

Studi pustaka adalah langkah untuk mencari berbagai dasar teori dan metode sebagai dasar yang dapat digunakan dan sesuai untuk menyelesaikan perumusan masalah yang ada. Sub bab teori yang digunakan dalam pembuatan penelitian ini yaitu Konsep Supply Chain Management (SCM), Hambatan pada Supply Chain Management (SCM), Bullwhip Effect, Distribusi, Distribution Requirement Planning (DRP), Lot Lizing, dan teori penunjang lainnya.

\section{Pengumpulan Data}

Selanjutnya adalah pengambilan data pada perusahaan terkait. Data yang diambil pada adalah data sekunder. Data merupakan soft file yang didalamnya terdapat data permintaan dari konsumen, permintaan dari pihak distributor ke parbrik, stock gudang distributor, dan data barang masuk.

\section{E. Pengolahan Data}

Setelah itu dilakukan pengolahan terhadap data yang telah ada. Ada beberapa macam pengolahan data yang dilakukan ini. Pertama menghitung nilai BE (Bullwhip Effect) dari data lama yang ada. Dilanjutkan dengan pembuatan tabel DRP (Distribution Requirement Planning). Setelah tabel DRP selesai maka dilakukan kembali penghitungan $\mathrm{BE}$ terhadap data setelah penerapan DRP.

\section{F. Analisis Data}

Analisa data berguna untuk mengetahui hasil dari pada pengolahan data terhadap penelitian ini. Dari hasil pengolahan data maka akan terlihat apakah dengan metode olah data seperti itu akan memberikan sebuah hasil yang di harapkan. Apakah setelah penerapan metode yang ada dapat membuat masalah di atasi atau dikurangi.

\section{G. Kesimpulan dan Saran}

Penarikan kesimpulan dan saran berguna untuk menjawab semua rumusan masalah yang ada dan juga tujuan. Selain itu juga berguna bagi perusahaan untuk sebuah acuan terhadap perbaikan apa saja yang perlu dilakukan dan bisa dilakukan untuk memperbaiki keadaan perusahaan. Dan saran bagi peneliti selanjutnya.

\section{Pengumpulan Data dan Analisis}

\section{A. Data Permintaan}

Studi kasus yang diambil dalam penelitian ini adalah masalah pada UD. Trimei yang merupakan distributor utama minyak goreng yang melayani wilayah Jawa Timur. Disini diambil dua jenis produk minyak goreng yang akan dianalisis yaitu produk Hemart $500 \mathrm{ml}$ dan Hemart $1000 \mathrm{ml}$. Data yang diambil adalah periode mingguan selama 14 minggu.

UD. Trimei melayani beberapa sub distributor yang ditunjukkan dengan struktur di bawah ini:

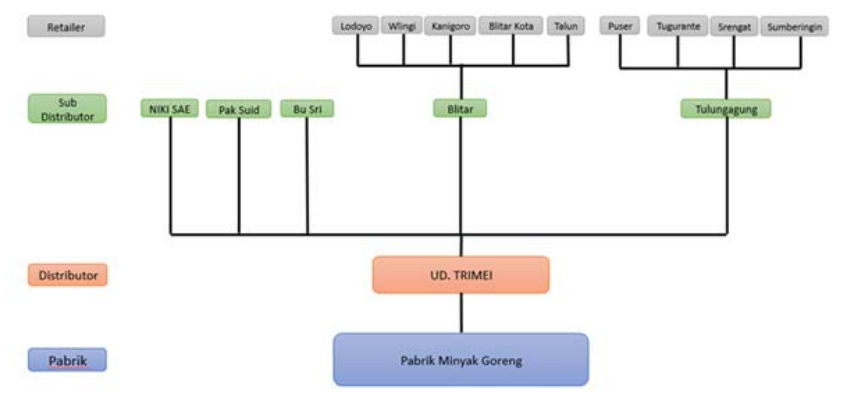

Gambar. 3. Struktur DRP

Data permintaan minyak goreng Hemart 500 dan Hemart $1000 \mathrm{ml}$ diperoleh dari level sub distributor. Data permintaan produk Hemart $500 \mathrm{ml}$ disajikan dalam gambar 4, sedangkan produk Hemart $1000 \mathrm{ml}$ disajikan dalam gambar 5.

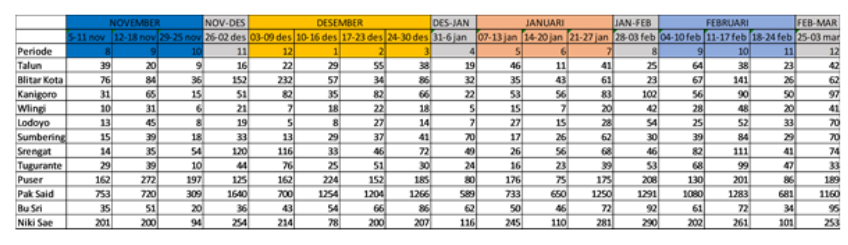

Gambar. 4. Tabel Data Permintaan Produk Hemart 500 ml

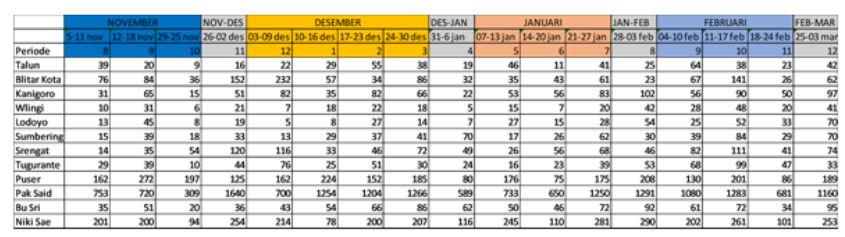

Gambar. 5. Tabel Data Permintaan Produk Hemart $1000 \mathrm{ml}$

\section{B. Pembuatan Tabel DRP}

Tabel DRP dibuat berdasarkan data permintaan dari setiap sub distributor dan mengikuti struktur distribusi pada gambar 3. Dan berikut adalah hasil akhir dari pembuatan tabel DRP pada level distributor UD Trimei disajikan dalam gambar 6 dan gambar 7 .

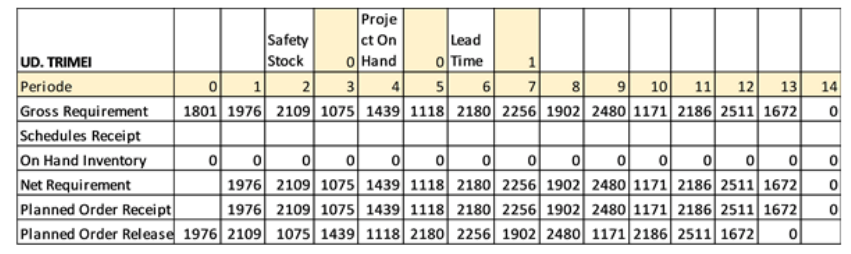

Gambar. 6. Tabel Hasil DRP Produk Hemart $500 \mathrm{ml}$ 


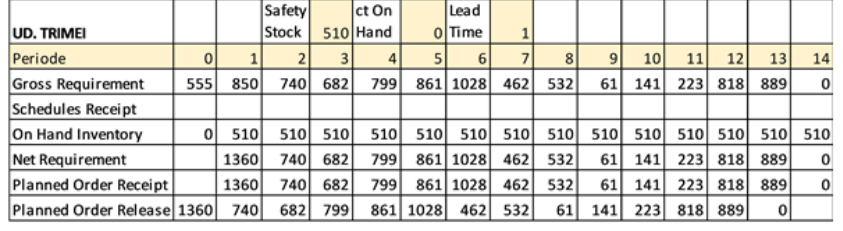

Gambar. 7. Tabel Hasil DRP Produk Hemart $1000 \mathrm{ml}$

Dari hasil Planned Order Release pada table DPR, didapatkan rencana pemesanan UD. Trimei ke perusahaan selama 12 periode. Hasil untuk kedua produk dirangkum dalam gambar 8 .

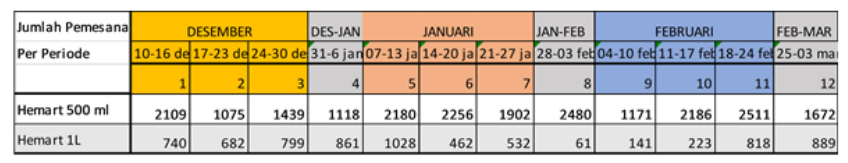

Gambar. 8. Tabel Output Pemesanan dari tabel DRP

\section{Penghitungan Nilai Bullwhip Effect (BE)}

Perhitungan nilai BE dilakukan pada dua kondisi, yaitu pada kondisi awal atau kondisi yang dilakukan perusahaan tanpa melakukan perhitungan DRP dan kondisi pada saat jumlah pemesanan dilakukan sesuai dengan hasil DRP. Perhitungan nilai BE memerlukan dua jenis data, yaitu data penjualan dan data pemesanan (order). Data permintaan adalah total keseluruhan permintaan dari konsumen, sedangkan data order adalah banyak barang yang diorder oleh UD. TRIMEI ke pabrik untuk setiap produk pada setiap minggunya.

1) Perhitungan BE pada kondisi awal atau sebelum penerapan metode DRP. Data penjualan dan order yang dilakukan UD trimei disajikan dalam gambar 9.

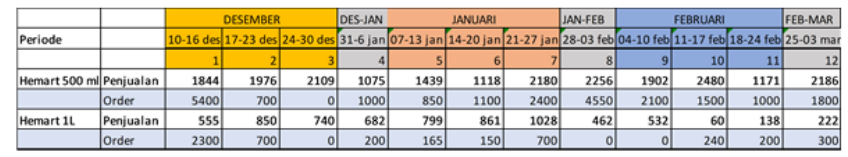

Gambar. 9. Tabel jumlah penjualan dan order yang dilakukan UD Trimei

Selanjutnya dihitung nilai BE sesuai dengan rumus:

$$
B E=C V o / C V d
$$

\footnotetext{
Di mana:

$\mathrm{CVo}=$ so $/$ muo

$\mathrm{CVd}=\mathrm{sd} / \mathrm{mud}$

Keterangan:

$\mathrm{BE}=$ bullwhip effect

CVo $=$ koefisien variansi order

$\mathrm{CVd}=$ koefisien variansi demand

So $\quad=$ standar deviasi order

sd $\quad=$ standar deviasi demand
}

TABEL I

PERHITUNGAN BE SEBELUM DRP

\begin{tabular}{ccccc}
\hline \hline & Rata-rata & Stand Dev & CV & BE \\
\hline Hemart 500 ml & 1811.3333 & 487.82436 & 0.269318 & 3.181043 \\
& 1866.6667 & 1599.1949 & 0.856712 & \\
Hemart 1 L & 577.41667 & 308.54953 & 0.534362 & 2.899184 \\
& 412.91667 & 639.69616 & 1.549214 & \\
\hline \hline
\end{tabular}

2) Perhitungan BE setelah penerapan metode DRP. Pada tahap ini data pemesanan yang digunakan adalah hasil dari perhitungan DRP. Sehingga data pemesanan seperti pada Gambar 10.

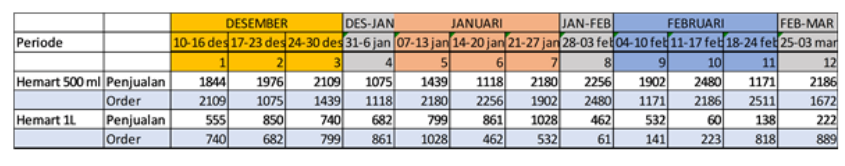

Gambar. 10. Tabel jumlah penjualan dan order hasil perhitungan DRP

Dengan rumus yang sama, diperoleh hasil perhitungan nilai BE seperti pada Gambar 11.

\begin{tabular}{|l|l|r|r|r|c|}
\hline \multirow{2}{*}{ Penghitungan } & & Rata-rata & Std. Deviasi & Koefisien Variansi & Bullwhip Effect \\
\cline { 3 - 6 } & & \multicolumn{1}{c|}{$\mathrm{m}$} & \multicolumn{1}{c|}{$\mathrm{s}$} & \multicolumn{1}{c|}{$\mathrm{CV}$} & \multicolumn{1}{c|}{ BE } \\
\hline Hemart 500 ml & Penjualan & 1842 & 529.792662 & 0.287683241 & 1.06819234 \\
\hline & Order & 1811 & 487.82436 & 0.269317828 & \\
\hline Hemart 1L & Penjualan & 603 & 318.400263 & 0.52802697 & 0.988144677 \\
\hline & Order & 577 & 308.549527 & 0.534362004 & \\
\hline
\end{tabular}

Gambar. 11. Tabel Perhitungan BE setelah Penerapan DRP

Hasil perhitungan nilai $\mathrm{BE}$ tersebut dirangkum dalam tabel II.

TABEL II

PERHITUNGAN NiLAi BE SEBELUM DAN SESUDAH DRP

\begin{tabular}{ccc}
\hline \hline Nilai BE & Sebelum Penerapan DRP & Sesudah Penerapan DRP \\
\hline Hemart 500 ml & 3.181042801 & 1.068192340 \\
Hemart 1 L & 2.89918387 & 0.988144677 \\
\hline \hline
\end{tabular}

Dapat dilihat pada penghitungan nilai BE diatas menunjukan bahwa nilai $\mathrm{BE}$ pada periode sebelum penerapan metode DRP tidak sesuai harapan dan tidak mendekati nilai 1 sama sekali yang menunjukan permintaan teramplifikasi sebanyak nilai tersebut dan cukup besar. Selanjutnya dapat dilihat juga pada tabel diatas, nilai BE yang dihasilkan sesudah penerapan DRP sesuai dengan harapan yaitu mendekati nilai 1 . Untuk nilai diatas 1 terjadi amplifikasi permintaan namun hanya sedikit karena hasilnya tidak terlampau jauh dari nilai 1 . Untuk nilai dibawah 1 berarti terjadi penghalusan pola permintaan.

Di halaman berikut adalah salah satu ilustrasi perbandingan bullwhip effect yang terjadi: 


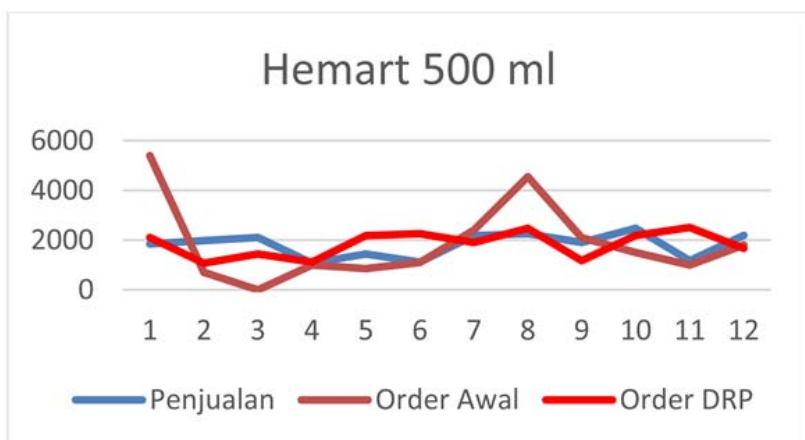

Gambar. 12. Grafik Bullwhip Effect sebelum DRP

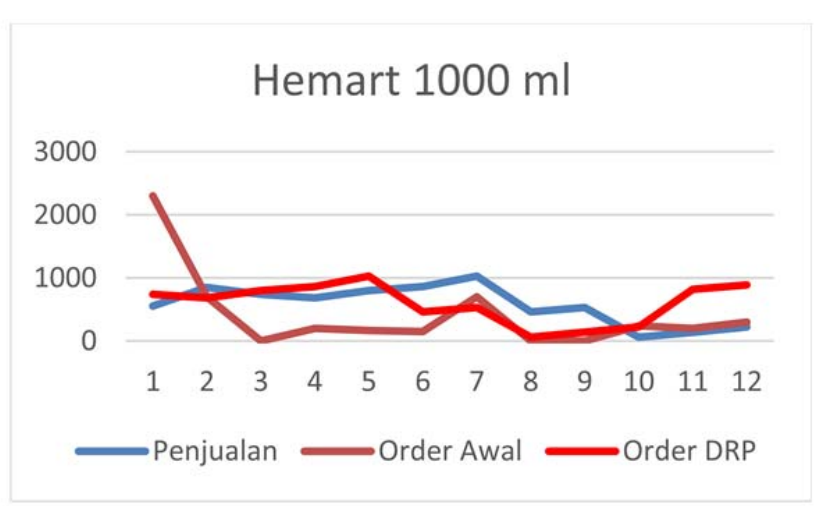

Gambar. 13. Grafik Bullwhip Effect sesudah DRP

\section{KESIMPULAN}

Kesimpulan dari penelitian ini adalah sebagai berikut:

1) Penerapan metode DRP pada aktifitas distribusi UD.Trimei tidak hanya mempermudah UD.Trimei untuk perencanaan barang untuk kebutuhan kedepan namun juga merupakan salah satu cara memperbaiki nilai $\mathrm{BE}$ yang terjadi pada tingkat distributor dan pabrik.

2) Penerapan metode DRP berpengaruh sangat baik terhadap nilai bullwhip effect yang ada. Seperti contoh pada produk Hemart $500 \mathrm{ml}$ yang memiliki nilai BE awal 3,181 setelah penerapan DRP nilai tersebut membaik menjadi 1.068. Begitu juga pada produk Hemart $1000 \mathrm{ml}$ terjadi perbaikan nilai BE, dari 2,899 mejadi 0,988.

\section{DAFTAR PUSTAKA}

[1] Bozarth, Cecil, C., Handfield, Robert, B. (2008).Introduction to Operations and Supply Chain Management. $2^{\text {nd }}$ Edition, New Jersey: Pearson Prentice Hall.

[2] Chopra, Sanil dan Meindl, Peter. (2001). Supply Chain Management. Northwestern University.

[3] Lee, Hau L., Padmanabhan, Whang, Seungjin, (1997). The Bullwhip Effect in Supply Chains. Magazine: Spring 1997, MIT Sloan Management Review.

[4] Marcelius Mada Barung. (2011). Thesis: Pengurangan Bullwhip Effect Pada Rantai Pasok di Level Distributor Y. Fakultas Teknik Universitas Hasanuddin, Makassar. 